\title{
PENGARUH RETURN ON EQUITY DAN EARNING PER SHARE TERHADAP HARGA SAHAM PADA PERUSAHAAN MANUFAKTUR SUB SEKTOR MAKANAN DAN MINUMAN YANG TERDAFTAR DI BURSA EFEK INDONESIA PERIODE 2012 - 2017
}

\author{
Winda Tristanti \\ Sari Marliani, Dra , MM
}

\begin{abstract}
ABSTRAK
Penelitian ini bertujuan untuk mengetahui pengaruh rasio keuangan terhadap harga saham pada perusahaan manufaktur sub sektor makanan dan minuman yang terdaftar di Bursa Efek Indonesia (BEI) selama periode 2012-2017 baik pengaruh secara parsial maupun simultan. Rasio keuangan yang penulis gunakan dalam penelitian ini adalah return on equity (ROE) dan earning per share (EPS). Populasi yang digunakan dalam penelitian ini adalah perusahaan manufaktur subsektor makanan dan minuman yang terdaftar di Bursa Efek Indonesia (BEI) pada tahun 2012-2017. Dalam penelitian ini sampel yang digunakan sebanyak 11 perusahaan. Metode yang digunakan dalam penelitian ini adalah metode deskriptif kuantitatif. Hasil pengujian hipotesis menunjukan bahwa secara bersama-sama return on equity dan earning per share signifikan terhadap harga saham, dengan nilai determinasi $38,31 \%$. Uji parsial menunjukan bahwa variabel return on equity dan earning per share mempunyai pengaruh positif dan signifikan terhadap harga saham.
\end{abstract}

Kata Kunci : Return On Equity (ROE), Earning Per Share (EPS), Harga Saham

ABSTRACT

This study aims to influence the financial ratios of stock prices in food and beverage sub-sector manufacturing companies listed on the Indonesia Stock Exchange (IDX) during the period 2012-2017, both partially and simultaneously. The financial ratios that I use in this study are return on equity (ROE) and earnings per share (EPS).The population used in this study is the food and beverage subsector manufacturing companies listed on the Indonesia Stock Exchange (IDX) in 2012-2017. In this study the sample used was 11 companies. The method used in this research is quantitative descriptive method. The results of hypothesis testing show that together return on equity and earnings per share have a significant effect on stock prices, with a determination value of $38,31 \%$. The partial test shows that the variable return on equity and earnings per share have a significant effect on stock prices.

Keywords: Return On Equity (ROE), Earning Per Share (EPS), Stock Price 


\section{Latar Belakang}

Adanya pasar modal dalam perekonomian modern sudah tidak asing lagi, termasuk di negara kita Indonesia. Meskipun Indonesia merupakan negara berkembang namun kebutuhan masyarakat akan barang dan jasa sangat tinggi. Hal ini dibuktikan dengan meningkatnya persaingan pada beberapa perusahaan di berbagai sektor. Perusahaan industri makanan dan minuman menjadi salah satu sektor manufaktur andalan dalam memberikan konstribusi besar terhadap pertumbuhan ekonomi nasional.

Peran penting ini terlihat dari konstribusinya yang konsisten dan signifikan terhadap produk domestik bruto (PDB) industri non-migas serta peningkatan realisasi investasi. Kementerian Perindustrian mencatat, sumbangan industri makanan dan minuman kepada PDB industri non-migas mencapai 34,95\% pada triwulan III tahun 2017. Kinerja ini menjadikan sub sektor tersebut menjadi kontributor PDB industri terbesar dibanding sub sektor lainnya. Harga saham merupakan harga yang terjadi di pasar bursa pada saat tertentu yang ditentukan oleh pelaku pasar, ditentukan oleh permintaan dan penawaran saham yang bersangkutan di pasar modal. Semakin banyak investor yang membeli saham, maka saham tersebut akan cenderung bergerak naik.

Return On Equity merupakan rasio yang digunakan untuk mengukur tingkat keuntungan perusahaan dengan membandingkan antara laba bersih setelah pajak dengan total modal sendiri. ROE yang tinggi mencerminkan bahwa perusahaan berhasil menghasilkan keuntungan dari modalnya sendiri dan bisa menaikkan nilai jual perusahaan yang berdampak pada kenaikan harga saham. Earning Per Share adalah rasio pasar yang digunakan untuk mengukur seberapa besar pengakuan pasar akan suatu perusahaan dengan membandingkan antara laba bersih dengan jumlah lembar saham yang beredar di pasaran.

\section{Rumusan Masalah}

1. Bagaimana pengaruh return on equity terhadap harga saham pada perusahaan manufaktur sub sektor makanan dan minuman yang terdaftar di Bursa Efek Indonesia periode 2012 - 2017 ? 
2. Bagaimana pengaruh earning per share terhadap harga saham pada perusahaan manufaktur sub sektor makanan dan minuman yang terdaftar di Bursa Efek Indonesia periode 2012 - 2017 ?

3. Bagaimana pengaruh return on equity dan earning per share secara simultan terhadap harga saham pada perusahaan manufaktur sub sektor makanan dan minuman yang terdaftar di Bursa Efek Indonesia periode 2012 - $2017 ?$

\section{TINJAUAN PUSTAKA}

\section{Pasar Modal}

Pasar modal merupakan pasar abstrak, dimana yang diperjual-belikan berupa dana jangka panjang yang berhubungan dengan investasi lebih dari satu tahun. Pasar modal sama dengan pasar-pasar lainnya, perbedaan pasar modal dengan pasar lainya terdapat pada komoditi yang diperdagangkan. Pasar modal merupakan tempat dimana berbagai pihak khususnya perusahaan menjual saham dan obligasi dengan tujuan dari hasil penjualan tersebut akan dipergunakan untuk memperkuat modal perusahaan (Irfam Fahmi, 2015:36)

\section{Rasio Keuangan}

Rasio keuangan merupakan alat analisis keuangan yang sering digunakan untuk memberikan informasi tentang laporan keuangan yang lebih luas dan lebih mendalam.

Menurut Munawir (2012:37) analisis rasio adalah suatu metode analisa untuk mengetahui hubungan dari pos-pos tertentu dalam neraca atau laporan laba rugi secara individu maupun kombinasi dari kedua laporan tersebut. Menurut Kasmir (2017:104) rasio keuangan adalah kegiatan membandingkan angka-angka yang ada dalam laporan keuangan dengan cara membagi satu angka dengan angka lainnya.

\section{Return On Equity}

Return On Equity merupakan rasio yang menunjukan seberapa besar perusahaan menghasilkan laba atau keuntungan dari hasil pengelolaan modal yang dimilikinya, baik modal sendiri maupun modal investor. Menurut Kasmir (2017:204) Return On Equity

$$
\text { Retum On Equity (ROE) }=\frac{\text { Earning After Taxes }}{\text { Shareholders Equity }} \times 100 \%
$$


(ROE) adalah rasio untuk mengukur laba bersih sesudah pajak dengan modal sendiri.

Berikut adalah rumus untuk mencari return on equity:

\section{Earning Per Share}

Earning Per Share (EPS) merupakan informasi yang dianggap paling mendasar dan berguna bagi para investor maupun calon investor, karena dapat menggambarkan prospek suatu perusahaan pada masa yang akan datang.

Menurut Hery (2016:144) laba per saham (EPS) merupakan rasio untuk mengukur keberhasilan manajemen perusahaan dalam memberikan keuntungan bagi para pemegang saham biasa.

Berikut adalah cara untuk mencari earning per share:

$$
\text { Laba Per Saham }=\frac{\text { Laba bersih }}{\text { saham biasa yang beredar }}
$$

\section{Harga Saham}

Harga saham merupakan harga penutupan pasar saham selama periode pengamatan untuk tiap-tiap jenis saham yang dijadikan sampel dan pergerakannya senantiasa diamati oleh para investor. Menurut Jogiyanto (2010:167) pengertian harga saham adalah harga suatu saham yang terjadi di pasar bursa pada saat tertentu yang ditentukan oleh pelaku pasar dan ditentukan oleh permintaan dan penawaran saham yang bersangkutan di pasar modal.

\section{Kerangka Pemikiran}

Gambar 2.1

Skema kerangka penelitian

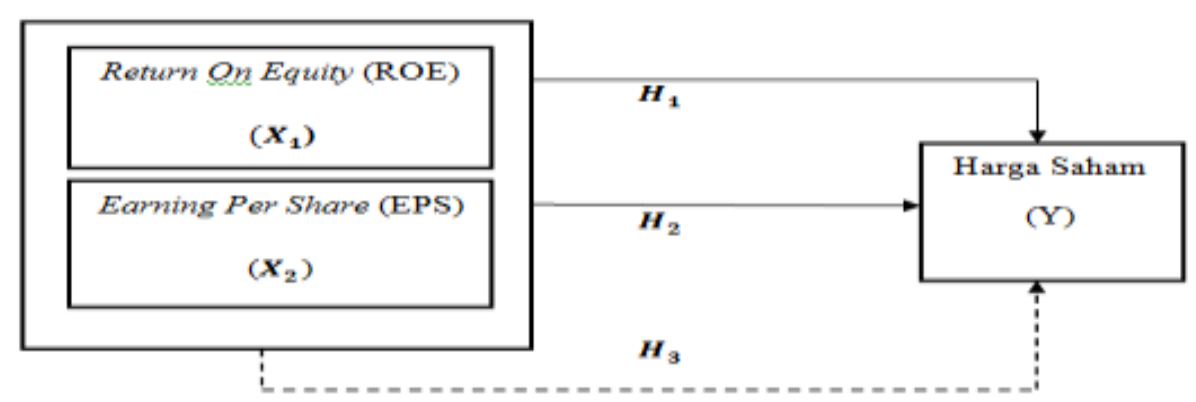




\section{Hipotesis Penelitian}

1. $H 0_{1}$ : Tidak terdapat pengaruh antara Return On Equity (ROE) terhadap harga saham

$H a_{1}$ : Terdapat pengaruh antara Return On Equity (ROE) terhadap harga saham.

2. $\mathrm{HO}_{2}$ : Tidak terdapat pengaruh antara Earning Per Share (EPS) terhadap harga saham

$\mathrm{Ha}_{2}$ : Terdapat pengaruh antara Earning Per Share (EPS) terhadap harga saham

3. $\mathrm{HO}_{3}$ : Tidak terdapat pengaruh secara simultan antara Return On Equity dan Earning Per Share terhadap harga saham

$\mathrm{Ha}_{3}$ : Terdapat pengaruh secara simultan antara Return On Equity dan Earning Per Share terhadap harga saham.

\section{TUJUAN DAN MANFAAT PENELITIAN}

\section{Tujuan dan Manfaat Penelitian}

\section{A. Tujuan Penelitian}

1. Untuk mengetahui pengaruh return on equity terhadap harga saham pada perusahaan manufaktur sub sektor makanan dan minuman yang terdaftar di Bursa Efek Indonesia periode $2012-2017$.

2. Untuk mengetahui pengaruh earning per share terhadap harga saham pada perusahaan manufaktur sub sektor makanan dan minuman yang terdaftar di Bursa Efek Indonesia periode $2012-2017$. 
3. Untuk mengetahui pengaruh return on equity dan earning per share secara simultan terhadap harga saham pada perusahaan manufaktur sub sektor makanan dan minuman yang terdaftar di Bursa Efek Indonesia periode 2012 - 2017.

B. Manfaat Penelitian

Penelitian ini berguna untuk :

1. Perusahaan Manufaktur sub sektor makanan dan minuman yang terdaftar di Bursa Efek Indonesia dalam mengetahui seberapa besar pengaruh return on equity dan earning per share terhadap harga saham di Bursa Efek Indonesia .

2. Dari hasil penelitian ini dapat dijadikan informasi bagi para Investor dalam membeli saham di Bursa Efek Indonesia dalam menerapkan dan faktor apa saja yang menjadi pengaruh terbesar terhadap harga saham di Perusahaan Manuaktur yang terdatar di Bursa Efek Indonesia.

3. Sebagai bahan evaluasi bagi perusahaan Manufaktur dalam mewujudkan kinerja perusahaan dalam meningkatkan kualitas yang lebih kompetitiv dan berdaya saing tinggi .

\section{METODE PENELITIAN}

Metode pengumpulan data dalam penelitian ini menggunakan dokumentasi. Data diperoleh dari laporan keuangan perusahaan manufaktur sub sektor makanan dan minuman periode tahun 2012-2017 yang telah terdaftar di Bursa Efek Indonesia, dan dapat diunggah melalui www.idx.co.id data penelitian ini juga diperoleh dari website www.finance.com. Populasi yang digunakan dalam penelitian ini adalah perusahaan manufaktur sub sektor makanan dan minuman yang terdaftar di Bursa Efek Indonesia (BEI) yaitu sebanyak 18 perusahaan. Teknik pengambilan sampel pada penelitian ini menggunakan teknik purposive sampling. Sampel yang digunakan pada penelitian ini sebanyak 11 perusahaan yang tidak mengalami kerugian. Penelitian ini menggunakan waktu periode selama 5 tahun yaitu tahun 2012-2017.

\section{Hasil dan Luaran Penelitian}

\section{A. Hasil Penelitian}




\section{a. Gambaran Objek Penelitian}

1. PT. Cahaya Kalbar

Wilmar Cahaya Indonesia Tbk (sebelumnya Cahaya Kalbar Tbk) didirikan pada tanggal 03 Februari 1968 dengan nama CV Tjahaja Kalbar dan mulai beroperasi secara komersial pada tahun 1971. Wilmar Cahaya Indonesia Tbk merupakan perusahaan dibawah Grup Wilmar International Limited. Wilmar International Limited adalah sebuah perusahaan yang mencatatkan sahamnya di Bursa Efek Singapura. Mulai terdaftar di Bursa Efek Indonesia (BEI) tapi tanggal 09 Juli 1996.

2. PT. Delta Djakarta Tbk

Delta Djakarta Tbk didirikan pada tanggal 15 Juni 1970 dan memulai kegiatan usaha komersialnya pada tahun 1933. Pabrik “Anker Bir" didirikan pada tahun 1932 dengan nama ArchipelBrouwerij. Dalam perkembangannya, kepemilikan dari pabrik ini telah mengalami beberapa kali perubahan hingga berbentuk PT Delta Djakarta pada tahun 1970. Berdasarkan Anggaran Dasar Perusahaan, ruang lingkup kegiatan DLTA yaitu terutama untuk memproduksi dan menjual bir pilsener dan bir hitam dengan merek "Anker", “Carlsberg", "San Miguel", "San Mig Light" dan "Kuda Putih".

\section{PT. Indofood CBP Sukses Makmur Tbk}

Indofood CBP Sukses Makmur Tbk didirikan pada tanggal 02 September 2009 dan mulai beroperasi secara komersial pada tanggal 1 Oktober 2009. Induk usaha dari Indofood CBP Sukses Makmur Tbk adalah INDF, dimana INDF memiliki 80,53\% saham yang ditempatkan dan disetor penuh ICBP, sedangkan induk usaha terakhir dari ICBP adalah First Pacific Company Limited (FP), Hong Kong.

4. PT. Indofood Sukses Makmur Tbk

Indofood Sukses Makmur Tbk didirikan pada tanggal 14 Agustus 1990 nama PT Pangan jaya Intikusuma dan memulai kegiatan usaha dengan 
komersialnya pada tahun 1990. Induk usaha dari Indofood Sukses Makmur Tbk adalah CAB Holding Limited (miliki 50,07\% saham INDF), Seychelles. Saat ini, Berdasarkan Anggaran Dasar Perusahaan, ruang lingkup kegiatan INDF antara lain terdiri dari mendirikan dan menjalankan industri makanan olahan, bumbu penyedap, minuman ringan, dll.

5.PT. Multi Bintang Indonesia Tbk

Multi Bintang Indonesia Tbk didirikan 03 Juni 1929 dengan nama N.V. Nederlandsch Indische Bierbrouwerijen dan mulai beroperasi secara komersial pada tahun 1929. Pemegang saham yang memiliki $5 \%$ atau lebih saham Multi Bintang Indonesia Tbk adalah Heineken International BV (pengendali) (81,78\%). Berdasarkan Anggaran Dasar Perusahaan, ruang lingkup kegiatan MLBI beroperasi dalam industri bir dan minuman lainnya. Saat ini, kegiatan utama MLBI adalah memproduksi dan memasarkan bir (Bintang dan Heineken), bir bebas alkohol (Bintang Zero) dan minuman ringan berkarbonasi (Green Sand).

6. PT. Mayora Indah Tbk

Mayora Indah Tbk didirikan 17 Februari 1977 dan mulai beroperasi secara komersial pada bulan Mei 1978. Pemegang saham yang memiliki 5\% atau lebih saham Mayora Indah Tbk, yaitu PT Unita Branindo (32,93\%), PT Mayora Dhana Utama (26,14\%) dan Jogi Hendra Atmadja (25,22\%). Saat ini Mayora menjalankan bidang usaha industri biskuit (Roma, Danisa, Royal Choice, Better, Muuch Better, Slai O Lai, Sari Gandum, dll), kembang gula (Kopiko, KIS, dll), wafer (beng beng, Astor, Roma), coklat (Choki-choki), kopi (Torabika dan Kopiko) dan makanan kesehatan (Energen) serta menjual produknya di pasar lokal dan luar negeri.

7. PT. Nippon Indosari Corpindo Tbk

Nippon Indosari Corpindo (Sari Roti) didirikan 08 Maret 1995 dengan nama PT Nippon Indosari Corporation dan mulai beroperasi komersial pada tahun 1996. Pemegang saham yang memiliki 5\% atau lebih saham Nippon Indosari Corpindo Tbk, antara lain: Indoritel Makmur Internasional Tbk 
(DNET) (31,50\%), Bonlight Investments., Ltd (25,03\%) dan Pasco Shikishima Corporation (8,50\%). Berdasarkan Anggaran Dasar Perusahaan, ruang lingkup usaha utama ROTI bergerak di bidang pabrikasi, penjualan dan distribusi roti dengan merek "Sari Roti".

8. PT. Sekar Bumi Tbk

Sekar Bumi Tbk didirikan 12 April 1973 dan mulai beroperasi secara komersial pada tahun 1974. Pemegang saham yang memiliki 5\% atau lebih saham Sekar Bumi Tbk, yaitu: TAEL Two Partners Ltd. (32,14\%), PT Multi Karya Sejati (pengendali) $(9,84 \%)$, Berlutti Finance Limited (9,60\%), Sapphira Corporation Ltd (9,39\%), Arrowman Ltd. (8,47\%), Malvina Investment $(6,89 \%)$ dan BNI Divisi Penyelamatan \& Penyelesaian Kredit Korporasi (6,14\%).Berdasarkan Anggaran Dasar Perusahaan, ruang lingkup kegiatan SKBM adalah dalam bidang usaha pengolahan hasil perikanan laut dan darat, hasil bumi dan peternakan.

9. PT. Siantar Top Tbk

Siantar Top Tbk didirikan tanggal 12 Mei 1987 dan mulai beroperasi secara komersial pada bulan September 1989. Pemegang saham yang memiliki 5\% atau lebih saham Siantar Top Tbk adalah PT Shindo Tiara Tunggal, dengan persentase kepemilikan sebesar 56,76\%. Berdasarkan Anggaran Dasar Perusahaan, ruang lingkup kegiatan Siantar Top terutama bergerak dalam bidang industri makanan ringan, yaitu mie (snack noodle, antara lain: Soba, Spix Mie Goreng, Mie Gemes, dll), kerupuk (crackers, seperti French Fries 2000, Twistko, dll), biskuit dan wafer (Goriorio, Gopotato, Go Malkist, dll), dan kembang gula.

10. PT. Sekar Laut

Tbk

Sekar laut Tbk didirikan pada tanggal 19 Juli 1976 dan mulai beroperasi secara komersial pada tahun 1976. Pemegang saham yang memiliki 5\% atau lebih saham Sekar Laut Tbk, antara lain : Omnistar Investment Holding Limited (26,78\%), PT Alamiah Sari (pengendali) (26,16\%), Malvina 
Winda Tristanti

Sari Marliani

Vol 4 No 1

ISSN : 2541-6995

E ISSN : 2580-5517

Investment Limited (17,22\%), Shadfort Agents Limited (13,39\%) dan Bank Negara Indonesia (Persero) Tbk (12,54\%). Saham - saham SKLT terdaftar di Bursa Efek Indonesia (BEI) pada tanggal 08 September 1993.

11. PT. Ultrajaya Milk Industry \& Trading Company Tbk

Ultrajaya Milk Industry \& Trading Company Tbk didirikan tanggal 2 November 1971 dan mulai beroperasi secara komersial pada awal tahun 1974. Pemegang saham yang memiliki 5\% atau lebih saham Ultrajaya Milk Industry \& Trading Company Tbk, antara lain: PT Prawirawidjaja Prakarsa $(21,40 \%)$, Tuan Sabana Prawirawidjaja (14,66\%), PT Indolife Pensiontana (8,02\%), PT AJ Central Asia Raya (7,68\%) dan UBS AG Singapore Non-

Treaty Acco Omibus (Kustodian)(7,42\%).




\section{B. Hasil Penelitian}

\section{a. Uji Statistik Deskriptif}

Berdasarkan data yang diperoleh dalam penelitian ini, peneliti menggunakan statistik deskriptif untuk mendeskripsikan gambaran umum pada objek yang diteliti dengan menggunakan sampel penelitian yang ada. Berikut adalah hasil uji statistik deskriptif :

\section{Analisis Deskriptif Statistik}

Tabel 1.

Descriptive Statistics

\begin{tabular}{|c|c|c|c|c|c|c|c|}
\hline & $\mathrm{N}$ & Minimum & Maximum & Sum & Mean & $\begin{array}{c}\text { Std. } \\
\text { Deviation }\end{array}$ & Variance \\
\hline \multirow{4}{*}{$\begin{array}{l}\text { Return On } \\
\text { Equity } \\
\text { Earning Per } \\
\text { Share } \\
\text { Harga Saham } \\
\text { Valid N } \\
\text { (listwise) }\end{array}$} & 66 & 2,53 & 143,53 & 1741,65 & 26,3886 & 32,13780 & 1032,838 \\
\hline & 66 & 14,92 & 18016,35 & 78420,11 & 1188,1835 & 3612,89928 & 13053041,197 \\
\hline & 66 & 180,00 & 30500,00 & 371568,00 & 5629,8182 & 6182,09161 & 38218256,643 \\
\hline & 66 & & & & & & \\
\hline
\end{tabular}

Tabel 1. diatas menjelaskan bahwa variabel Return On Equity (ROE) menunjukan nilai minimum sebesar 2,53 nilai maximum sebesar 143,53 nilai mean (rata-rata) sebesar 26,3886 dengan standar deviasi sebesar 32,13780. Pada tahun 2014 PT. Multi Bintang Indonesia Tbk memiliki nilai ROE tertinggi sebesar 143,53 dan pada tahun 2017 PT. Sekar Bumi Tbk memiliki nilai ROE terendah sebesar 2,53.

Earning Per Share (EPS) menunjukan nilai minimum sebesar 10,92 dan nilai maximum sebesar 1.8016,35 nilai mean (rata-rata) sebesar 1.188,1835 dengan standar deviasi sebesar 3.612,89928. Pada tahun 2014 PT.Delta Djakarta Tbk memiliki nilai EPS tertinggi sebesar 1.188,1835 dan pada tahun 2012 PT. Sekar Bumi Tbk memiliki nilai EPS terendah sebesar 10,92. 
Winda Tristanti

Sari Marliani

Vol 4 No 1

ISSN : 2541-6995

E ISSN : 2580-5517

Harga saham menunjukan nilai minimum sebesar 180,00 dan nilai maximum sebesar 30500,00 nilai mean (rata-rata) sebesar 5629,8182 dengan standar deviasi 6182,09161. Pada tahun 2015 PT. Mayora Indah Tbk memiliki harga saham tertinggi sebesar 30.500 dan pada tahun 2012 -2013 PT. Sekar Laut Tbk memiliki harga saham terendah sebesar 180.

\section{Uji Asumsi Klasik}

\section{a. Uji Normalitas}

Tabel 4.4

Hasil Uji Normalitas Setelah Transformasi

One-Sample Kolmogorov-Smirnov Test

\begin{tabular}{|ll|r|}
\hline & & $\begin{array}{r}\text { Unstandardize } \\
\text { d Residual }\end{array}$ \\
\hline Normal Parameters ${ }^{\mathrm{a}, \mathrm{b}}$ & Mean & 66 \\
& Std. Deviation &, 0000000 \\
Most Extreme Differences & Absolute &, 98450632 \\
& Positive &, 068 \\
& Negative &, 052 \\
Test Statistic & &,- 068 \\
Asymp. Sig. (2-tailed) & &, 068 \\
\hline
\end{tabular}

a. Test distribution is Normal.

b. Calculated from data.

c. Lilliefors Significance Correction.

d. This is a lower bound of the true significance.

Berdasarkan dari tabel 4.4 setelah dilakukan transformasi data (Ln) dapat diketahui nilai probabilitas signifikansi (Asymp Sig (2tailed) sebesar 0,200. Maka dapat disimpulkan bahwa data berdistribusi normal dan model regresi memenuhi asumsi normalitas karena memiliki nilai signifikansi diatas 0,05.

\section{b. Uji Heteroskedastisitas}


Winda Tristanti

Sari Marliani

Vol 4 No 1

ISSN : 2541-6995

E ISSN : $2580-5517$

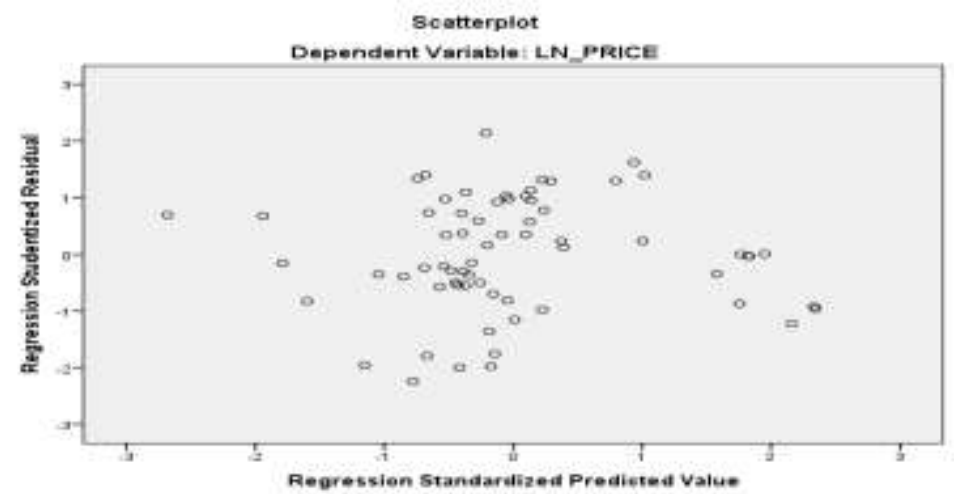

Berdasarkan hasil dari gambar scatterplot, didapatkan titik-titik menyebar secara acak serta tersebar dibawah maupun diatas angka 0 pada sumbu Y dan tidak mempunyai pola yang teratur, jadi dapat disimpulkan bahwa pada penelitian ini tidak terjadi heteroskedastisitas.

\section{c. Uji Multikolinearitas}

Tabel 4.5

Hasil Uji Multikolinearitas $\operatorname{Ln} X_{1}, \operatorname{Ln} X_{2}, \operatorname{Ln} Y$

\begin{tabular}{|c|c|c|c|c|c|c|c|}
\hline & & & Coefficients $^{a}$ & & & & \\
\hline \multirow[t]{2}{*}{ Model } & \multicolumn{2}{|c|}{$\begin{array}{l}\text { Unstandardized } \\
\text { Coefficients }\end{array}$} & $\begin{array}{c}\text { Standardized } \\
\text { Coefficients }\end{array}$ & \multirow[t]{2}{*}{$\mathrm{t}$} & \multirow[t]{2}{*}{ Sig. } & \multicolumn{2}{|c|}{$\begin{array}{l}\text { Collinearity } \\
\text { Statistics }\end{array}$} \\
\hline & $B$ & Std. Error & Beta & & & Tolerance & VIF \\
\hline 1 (Constant) & 4,505 &, 573 & & 7,867 &, 000 & & \\
\hline LN_ROE & 615 & 170 & 383 & 3,626 & ,001 & 879 & 1,137 \\
\hline LN_EPS & ,314 & ,089 & 372 & 3,521 & ,001 & 879 & 1,137 \\
\hline
\end{tabular}

a. Dependent Variable: LN_PRICE

Berdasarkan hasil uji multikolinearitas pada tabel 4.5 diatas, nilai VIF untuk variabel return on equity dan earning per share yaitu 1,137 nilai tolerance 0,879 . Hasil tabel diatas menunjukan bahwa nilai tolerance untuk semua variabel > 0,10 dan nilai VIF < 10. Maka dapat disimpulkan bahwa variabel return on equity dan earning per share terbebas dari asumsi klasik multikolinearitas.

\section{d. Uji Autokorelasi}


Winda Tristanti

Sari Marliani

Vol 4 No 1

ISSN : 2541-6995

E ISSN : $2580-5517$

Tabel 4.6

Hasil Uji Autokorelasi $\operatorname{Ln} X_{1}, \operatorname{Ln} X_{2}, \operatorname{Ln} Y$

Model Summary

\begin{tabular}{|l|r|r|r|r|r|}
\hline Model & $R$ & $R$ Square & \multicolumn{1}{c|}{$\begin{array}{c}\text { Adjusted } R \\
\text { Square }\end{array}$} & $\begin{array}{c}\text { Std. Error of the } \\
\text { Estimate }\end{array}$ & Durbin-Watson \\
\hline 1 &, $619^{a}$ &, 383 &, 364 & 1,00001 &, 803 \\
\hline
\end{tabular}

a. Predictors: (Constant), LN_EPS, LN_ROE

b. Dependent Variable: LN_PRICE

Berdasarkan hasil dari pengujian uji autokorelasi pada tabel 4.6 tentang pengaruh return on equity dan earning per share terhadap harga saham pada perusahaan manufaktur sub sektor makanan dan minuman, diketahui nilai Durbin Watson sebesar 0,803. Dimana nilai tersebut terletak diantara -2 sampai +2 . Jadi dapat disimpulkan bahwa tidak terjadi autokorelasi pada penelitian ini.

\section{e. Uji Analisis Regresi Linear Berganda}

Tabel 4.7

Hasil Uji Regresi Linear Berganda $\operatorname{Ln} X_{1}, \operatorname{Ln} X_{2}$, Ln Y

Coefficients $^{a}$

\begin{tabular}{|c|c|c|c|c|c|}
\hline \multirow[b]{2}{*}{ Model } & \multicolumn{2}{|c|}{$\begin{array}{l}\text { Unstandardized } \\
\text { Coefficients }\end{array}$} & \multirow{2}{*}{$\begin{array}{c}\begin{array}{c}\text { Standardized } \\
\text { Coefficients }\end{array} \\
\text { Beta }\end{array}$} & \multirow[b]{2}{*}{$\mathrm{t}$} & \multirow[b]{2}{*}{ Sig. } \\
\hline & $B$ & Std. Error & & & \\
\hline 1 (Constant) & 4,505 &, 573 & & 7,867 &, 000 \\
\hline LN_ROE & ,615 & , 170 & ,383 & 3,626 & ,001 \\
\hline LN_EPS & 314 & ,089 & ,372 & 3,521 & ,001 \\
\hline
\end{tabular}


a. dependent Variable: LN_PRICE

a. Konstanta sebesar 4,505 artinya jika variabel independen dianggap konstan, maka harga saham yang dihasilkan sebesar 4,505.

b. Koefisien regresi return on equity $\left(X_{1}\right)$ sebesar 0,615 bernilai positif. Hal ini menunjukkan pada saat return on equity mengalami kenaikan sebesar Rp 1 variabel, maka harga saham akan mengalami kenaikan sebesar Rp 0,615 dengan asumsi variabel independen lain bernilai tetap.

c. Koefisien regresi earning per share $\left(X_{2}\right)$ sebesar 0,314 bernilai positif. Hal ini menunjukkan pada saat earning per share mengalami kenaikan sebesar Rp 1 variabel, maka harga saham akan mengalami kenaikan sebesar Rp 0,314 dengan asumsi variabel independen lain bernilai tetap. Ketika earning per share mengalami kenaikan, maka jumlah pencapaian harga saham akan mengalami kenaikan. Begitu juga pada saat earning per share mengalami penurunan maka jumlah pencapaian harga saham akan turun.

\section{Pengujian Hipotesis}

a. Uji Koefisien Determinasi

Tabel 4.8

Hasil Uji Koefisien Determinasi $\operatorname{Ln} X_{1}, \operatorname{Ln} X_{2}, \operatorname{Ln} Y$

\begin{tabular}{|l|r|r|r|c|}
\hline Model & \multicolumn{1}{|c|}{ Model Summary } \\
\hline 1 &, $619^{\mathrm{a}}$ & R Square & $\begin{array}{c}\text { Adjusted R } \\
\text { Square }\end{array}$ & $\begin{array}{c}\text { Std. Error of the } \\
\text { Estimate }\end{array}$ \\
\hline
\end{tabular}

a. Predictors: (Constant), LN_EPS, LN_ROE

b. Dependent Variable: LN_PRICE

Sumber : SPSS Versi 23 (data diolah 2019) 
Berdasarkan tabel 4.8 diatas dapat diketahui nilai koefisien determinasi $\left(\mathrm{R}^{2}\right)$ adalah sebesar $38,31 \%$. Hal ini menunjukan bahwa kemampuan variabel independen yaitu return on equity dan earning per share dalam menjelaskan variabel dependen yaitu harga saham adalah sebesar 38,31\%. Sehingga dapat disimpulkan bahwa harga saham dipengaruhi return on equity dan earning per share sebesar 38,31\%, sedangkan sisanya sebesar $(100 \%-38,31 \%=61,69 \%)$ dipengaruhi oleh variabel lain yang belum diteliti dalam penelitian ini.

\section{b. Uji t Statistik (Uji-t)}

Tabel 4.9

Hasil Uji t Statistik (Uji-t) $\operatorname{Ln} X_{1}, \operatorname{Ln} X_{2}, \operatorname{Ln} Y$

Coefficients $^{a}$

\begin{tabular}{|c|c|c|c|c|c|c|}
\hline \multirow{2}{*}{\multicolumn{2}{|c|}{ Model }} & \multicolumn{2}{|c|}{$\begin{array}{l}\text { Unstandardized } \\
\text { Coefficients }\end{array}$} & \multirow{2}{*}{$\begin{array}{c}\text { Standardized } \\
\text { Coefficients } \\
\text { Beta }\end{array}$} & \multirow[b]{2}{*}{$\mathrm{t}$} & \multirow[b]{2}{*}{ Sig. } \\
\hline & & $B$ & Std. Error & & & \\
\hline \multirow[t]{3}{*}{1} & (Constant) & 4,505 &, 573 & & 7,867 & ,000 \\
\hline & LN_ROE & ,615 & , 170 & ,383 & 3,626 & ,001 \\
\hline & LN_EPS & ,314 & ,089 & ,372 & 3,521 &, 001 \\
\hline
\end{tabular}

Berdasarkan nilai uji t yang diperoleh pada tabel 4.9 diatas, secara parsial pengaruh variabel independen terhadap variabel dependen adalah sebagai berikut:

\section{Pengaruh Return On Equity Terhadap Harga Saham}

Dari hasil analisis return on equity $\left(X_{1}\right)$ terhadap harga saham (Y) secara parsial dengan diperoleh nilai $t_{\text {hitung }}$ sebesar 3,626 dan nilai $t_{\text {tabel }}$ 1,998 dengan nilai signifikansi sebesar 0,001 . Nilai $t_{\text {hitung }} 3,626>$ nilai $t_{\text {tabel }}$ 1,998 dan nilai signifikansi sebesar 0,001 $<0,05$ maka $\mathrm{H}_{0}$ ditolak dan $\mathrm{H}_{\mathrm{a}}$ diterima, dengan kata lain bahwa terdapat pengaruh signifikan antara return on equity $\left(\mathrm{X}_{1}\right)$ terhadap harga saham $(\mathrm{Y})$.

\section{Pengaruh Earning Per Share Terhadap Harga Saham}


Winda Tristanti

Sari Marliani

Vol 4 No 1

ISSN : 2541-6995

E ISSN : 2580-5517

Dari hasil analisis earning per share $\left(X_{2}\right)$ terhadap harga saham (Y) secara parsial diperoleh dengan nilai $t_{\text {hitung }}$ sebesar 3,521 dan nilai $t_{\text {tabel }}$ sebesar 1,998 dengan nilai signifikasi sebesar 0,001. Nilai thitung sebesar $3,521>$ nilai $t_{\text {tabel }}$ sebesar 1,998 dan nilai signifikan sebesar 0,001 $<0,05$ maka $\mathrm{H}_{0}$ ditolak dan $\mathrm{H}_{\mathrm{a}}$ diterima, dengan kata lain bahwa terdapat pengaruh signifikan antara earning per share $\left(\mathrm{X}_{2}\right)$ terhadap harga saham $(\mathrm{Y})$.

\section{b. Uji Simultan (Uji-F)}

Tabel 4.10

Hasil Uji Signifikan Simultan (Uji-F) $\operatorname{Ln} \mathrm{X}_{1}, \operatorname{Ln} \mathrm{X}_{2}, \operatorname{Ln} \mathrm{Y}$

\begin{tabular}{|c|c|c|c|c|c|}
\hline \multicolumn{6}{|c|}{ ANOVA $^{a}$} \\
\hline Model & $\begin{array}{l}\text { Sum of } \\
\text { Squares }\end{array}$ & Df & Mean Square & $\mathrm{F}$ & Sig. \\
\hline 1 Regression & 39,148 & 2 & 19,574 & 19,574 &, $000^{b}$ \\
\hline Residual & 63,001 & 63 & 1,000 & & \\
\hline Total & 102,150 & 65 & & & \\
\hline
\end{tabular}

Berdasarkan tabel 4.10 diatas dapat dilihat bahwa dalam pengujian uji simultan $\mathrm{F}$ menunjukan hasil $\mathrm{F}_{\text {hitung }}$ sebesar 19,574 dan hasil $\mathrm{F}_{\text {tabel }}$ sebesar $3,14(19,574>3,14)$ dengan tingkat signifikan $0,000<0,05$ yang artinya $\mathrm{H}_{0}$ ditolak dan $\mathrm{H}_{\mathrm{a}}$ diterima, dengan kata lain bahwa secara simultan return on equity dan earning per share berpengaruh positif dan signifikan terhadap harga saham.

\section{Luaran Yang Di capai}

Dibawah ini luaran yang dicapai dalam penelitian ini :

\begin{tabular}{|l|l|l|l|}
\hline No & Luaran Yang dicapai & Capaian & Keterangan \\
\hline 1 & & & \\
\hline 2 & & & \\
\hline
\end{tabular}

\section{E. Kesimpulan dan Saran}


1. Berdasarkan hasil pengujian secara parsial (Uji-t) variabel return on equity dengan nilai $t_{\text {hitung }}$ sebesar 3,626 dan nilai $t_{\text {tabel }}$ sebesar 1,998 (3,626> 1,998) dengan nilai signifikan sebesar $0,001<0,05$. Jadi dapat disimpulkan bahwa return on equity berpengaruh signifikan terhadap harga saham pada perusahaan manufaktur sub sektor makanan dan minuman yang terdaftar di Bursa Efek Indonesia periode 2012-2017.

Berdasarkan hasil pengujian secara parsial (Uji-t) variabel earning per

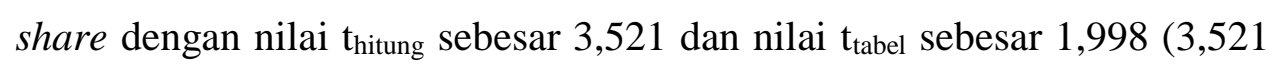
$>1,998$ ) dengan nilai signifikasi sebesar $0,001<0,05$. Jadi dapat disimpulkan bahwa earning per share berpengaruh signifikan terhadap harga saham pada perusahaan manufaktur sub sektor makanan dan minuman yang terdaftar di Bursa Efek Indonesia periode 2012-2017.

2. Berdasarkan hasil pengujian secara simultan (Uji-F) variabel return on equity dan earning per share berpengaruh secara bersama-sama (simultan) dengan nilai signifikansi sebesar $0,000<0,05$. Jadi dapat disimpulkan return on equity dan earning per share berpengaruh signifikan terhadap harga saham pada perusahaan manufaktur sub sektor makanan dan minuman yang terdaftar di Bursa Efek Indonesia periode 2012-2017. Besar pengaruh kedua variabel secara simultan sebesar 38,31\% dan sisanya dipengaruhi oleh variabel lain yang tidak peneliti gunakan dalam penelitian ini.

\section{Saran}

Berdasarkan hasil penelitian return on equity dan earning per share memiliki pengaruh positif dan signifikan terhadap harga saham. Sebaiknya perusahaan tetap meningkatkan return on equity dan earning per share dengan mengoptimalkan penggunaan modal sendiri dan memaksimumkan nilai lembar per saham agar menghasilkan laba bersih 
yang lebih efektif. Karena laba bersih merupakan salah satu indikator yang menjadi pertimbangan investor sebelum menanamkan sahamnya.

Semakin tinggi return on equity dan earning per share maka semakin tinggi pula harga saham. Begitu pula jika semakin rendah return on equity dan earning per share maka semakin rendah harga saham, hal ini menjadikan minat investor untuk menanamkan sahamnya menjadi berkurang.

\section{DAFTAR PUSTAKA}

Aisah , Nurhayani Ayu. 2016. Pengaruh Return On Equity, Earning Per Share, Firm Size dan Operating Cash Flow Terhadap Return Saham. Fakultas Bisnis dan Illmu Sosial. E-Jurnal Manajemen Unud, Vol.4, No.12, 2015. ISSN : 2302-8912. Universitas Udayana Bali.

Brigham dan Houston. 2010. Dasar-dasar Manajemen Keuangan Buku 1. Edisi 11. Jakarta : Salemba Empat.

Fahmi, Irham. 2014. Manajemen Keuangan Pasar Modal. Jakarta : Mitra Wacana Media.

- 2015. Pengalaman Manajemen KeuanganTeori dan Soal Jawa. Bandung : Alfabeta.

Fahrudin, Darmaji. 2012. Pasar Modal Indonesia. Edisi ke tiga. Jakarta : Salemba Empat.

Ghozali, Imam. 2011. Aplikasi Analisis Multivariate dengan Program IBM SPSS 19. Semarang : Badan Penerbit Universitas Diponegoro.

Hidayat, Taufik. 2011. Kaya Sekarang Juga! Cara Pintar Investasi Emas dan Dinar. Jakarta : Media Kita

Jogiyanto. 2010. Teori Portofolio dan Analisis Investasi. Edisi 7. Yogyakarta : BPFE Yogyakarta.

2015. Teori Portofolio dan Analisis Investasi. Edisi 10. Yogyakarta : BPFE Yogyakarta.

Kardinal, Wilda., dan Elizabeth, Sri Megawati. 2018. Pengaruh ROE, CR, EPS Terhadap Harga Saham Perusahaan Makanan dan Minuman Yang 
Winda Tristanti

Sari Marliani Vol 4 No 1

ISSN : 2541-6995

E ISSN : $2580-5517$

Terdaftar Di Bursa Efek Indonesia Tahun 2013-2016. Jurusan Manajemen. STIE Multi Data Palembang.

Kasmir. 2017. Analisis Laporan Keuangan. Jakarta : Grafindo Persada.

Lestari, Tri Ninda. 2018. Analisis Pengaruh Kinerja Keuangan Terhadap Harga Saham Pada Perusahaan Pertanian Yang Terdaftar Di Bursa Efek Indonesia. Jurusan Manajemen. Fakultas Bisnis dan Ilmu Sosial. Universitas Muhammadiyah Surakarta.

Mulyawan, Setia. 2015. Manajemen Keuangan. Bandung : Pustaka Setia.

Rahmawati, Pande Widya.,dan Abundanti, Nyoman. 2018. Pengaruh EPS,PER,CR dan ROE Terhadap Harga Saham Di Bursa Efek Indonesia. Fakultas Ekonomi dan Bisnis. E-Jurnal Manajemen Unud, Vol.7, No.4, 2018. ISSN : 2302-8912. Universitas Udayana Bali.

Riyanto, Bambang. 2012. Dasar-Dasar Pembelanjaan (Edisi 4). Yogyakata : BPFE.

Sari, Heni Zulia., dan Hakim, Astrid Dita Meirina. 2017. Pengaruh Curent Ratio, Return On Equity, Debt to Equity Ratio dan Earning Per Share Terhadap Harga Saham Pada Perusahaan Sub Sektor Property dan Real Estate Di Bursa Efek Indonesia Periode 2012-2015. Fakultas Ekonomi dan Bisnis, Vol.6, No.2 Oktober 2017. ISSN : 2252-6226. Universitas Budi Luhur.

Sari, Ni Made Puspita Dewi., dan Triaryati, Nyoman. 2012. Analisis Pengaruh Profitabilitas, EPS, PER Terhadap Harga Saham Pada Perusahaan Perbankan di Bursa Efek Indonesia : Sebagai Dasar Pengambilan Keputusan Investasi. Fakultas Bisnis dan Ilmu Sosial. Universitas Udayana Bali.

Sriwahyuni, Endah.,dan Saputra, Rishi Septa. 2017. Pengaruh CR, DER, ROE, TAT dan EPS Terhadap Harga Saham Industri Farmasi Di Bursa Efek Indonesia Tahun 2011-2015. Jurnal Online Insan Akuntan, Vol.2, No.1, Juni 2017, 119-136. E-ISSN : 2528-0163. Akademi Akuntansi Bina Insani.

Sugiyono. 2013. Metode Penelitian Kuantitatif, Kualitatid Dan R\&D. Bandung : Alfabeta.

Suharno. 2016. Pengaruh Rasio Keuangan Terhadap Harga Saham Perusahaan Farmasi Yang Terdaftar Di Bursa Efek Indonesia Tahun 2010-2014. Skripsi. Ekonomi.Universitas Negeri Yogyakarta.

Triana, Kentut Tanta., dan Dewi, Sayu Kt Sutrisna. 2015. Peran EPS Dalam Memadai Pengaruh ROE Terhadap Harga Saham Perusahaan Perbankan Di Bursa Efek Indonesia. Fakultas Ekonomi dan Bisnis. E- 
Winda Tristanti

Sari Marliani Vol 4 No 1

ISSN : 2541-6995

E ISSN : $2580-5517$

Jurnal Manajemen Unud, Vol.4, No.12. ISSN : 2302-8912. Universitas Udayana Bali.

Utami, Martina Rut.,dan Darmawan, Arif. 2018. Pengaruh DER,ROA,ROE,EPS dan MVA Terhadap Harga Saham Pada Indeks Harga Saham Syariah Indonesia. Program Studi Manajerial. Journal Of Applied Managerial Accounting, Vol.2, No.2, September 2018, Page 77-89. Politeknik Negeri Batam.

Wulandari, Dwi. 2015. Analisis Pengaruh EPS, ROE, DER Terhadap Harga Saham Pada Perusahaan Transportation Services Yang Terdaftar Di Bursa Efek Indonesia Tahun 2012-2013. Fakultas Bisnis dan Ilmu Sosial. Universitas Muhammadiyah Surakarta.

www.idx.co.id, Laporan Keuangan Perusahaan Makanan dan Minuman Periode 2012-2017 